The Canadian Mineralogist

Vol. 38, pp. 1419-1424 (2000)

\title{
STRUCTURE REFINEMENT OF BAZZITE FROM PEGMATITIC AND MIAROLITIC OCCURRENCES
}

\author{
FRANCESCO DEMARTIN \\ Dipartimento di Chimica Strutturale e Stereochimica Inorganica, Università degli Studi, \\ via Venezian 21, I-20133 Milano, Italy \\ CARLO MARIA GRAMACCIOLI \\ Dipartimento di Scienze della Terra, Sezione di Mineralogia, Università degli Studi, \\ via Botticelli 23, I-20133 Milano, Italy \\ TULLIO PILATI \\ CNR, Centro per lo Studio delle Relazioni tra Struttura e Reattività Chimica, \\ via Golgi 19, I-20133 Milano, Italy
}

ABSTRACT

The crystal structure of two samples of bazzite, from the Baveno granite, in Piemonte, Italy (type locality, miarolitic occurrence) and from Tørdal, Norway (pegmatitic occurrence), has been refïned. Compared to material from Alpine fissures, these specimens contain greater amounts of heavy alkali ions $\left(\mathrm{Cs}^{+}, \mathrm{Rb}^{+}\right.$, and $\left.\mathrm{K}^{+}\right)$in the channels and minor quantities of magnesium in the octahedral positions, in agreement with the results of electron-microprobe analyses. In the channels, the $\mathrm{Na}^{+}$ions lie at the center of the $\mathrm{Si}_{6} \mathrm{O}_{18}$ rings, i.e., in the Wyckoff position $b$, whereas $\mathrm{H}_{2} \mathrm{O}$ and the heavier alkali ions occupy the $a$ position. The possibility of partial substitution of silicon by beryllium, which was inferred for bazzite by some authors on the grounds of chemical analysis, has not been confirmed.

Keywords: bazzite, miarolitic cavity, pegmatite, scandium, crystal-structure refinement, Baveno, Italy, Tørdal, Norway.

\section{SOMMAIRE}

Nous avons affiné la structure cristalline de deux échantillons de bazzite, un provenant de la localité-type, le granite de Baveno, région de Piemonte, en Italie (miarole), et l'autre provenant de Tørdal, en Norvège (pegmatite). En comparaison avec la bazzite de fentes alpines, ces deux échantillons contiennent davantage d'alcalins lourds $\left(\mathrm{Cs}^{+}, \mathrm{Rb}^{+}\right.$, et $\left.\mathrm{K}^{+}\right)$dans les canaux, et des quantités mineures de magnésium dans les positions octaédriques, en accord avec les mesures faites avec un microsonde électronique. Dans les canaux, les ions $\mathrm{Na}^{+}$sont situés au centre des anneaux $\mathrm{Si}_{6} \mathrm{O}_{18}$, à la position $b$ dans le système de Wyckoff, tandis que les molécules de $\mathrm{H}_{2} \mathrm{O}$ et les alcalins lourds occupent la position $a$. La possibilité d'une substitution partielle du béryllium au silicium, qui avait été evoquée dans la bazzite par certains auteurs à la lumière de résultats d'analyses chimiques, n'a pas été confirmée.

(Traduit par la Rédaction)

Mots-clés: bazzite, miarole, pegmatite, scandium, affinement de la structure cristalline, Baveno, Italie, Tørdal, Norvège.

\$ E-mail address: demartin@csmtbo.mi.cnr.it 


\section{INTRODUCTION}

Artini (1915) made the original discovery of bazzite in the miaroles of the Baveno granite, then the second known scandium-rich mineral. A number of additional occurrences of the mineral have since been reported in Alpine fissures (Hänni 1980, and references therein), and in granitic pegmatites outside the Alps, as for instance in Kazakhstan (Chistyakova et al. 1966) and in Norway (Bergst $\varnothing 1$ \& Juve 1988). In spite of the relative abundance of data concerning all these occurrences, the results of accurate crystal-structure refinements are scarce in the literature, the only notable exception being the recent study by Armbruster et al. (1995) on a specimen from an Alpine fissure in Furkabasistunnel, Switzerland.

Some differences have been noted between bazzite occurring in Alpine fissures and that from granitic pegmatites. For instance, the former contains significant amounts of magnesium, whereas the latter contains much less $\mathrm{Mg}$ but non-negligible amounts of heavy alkali metals, such as cesium, in the channels of the structure, as is common with beryl-group minerals (Gramaccioli et al. 2000). As different distributions of such ions (and $\mathrm{H}_{2} \mathrm{O}$ molecules) in the channels have been proposed for beryl by various authors (see below), additional crystallographic data for bazzite could well be useful to clarify the situation for all the minerals in the group.

The beryllium content of bazzite has been quantitatively determined by very few authors. Among these, Chistyakova et al. (1966) and Juve \& Bergstøl (1990) studied specimens from Kazakhstan and Norway, respectively, and reported a chemical formula in which part of the silicon seems to be replaced by beryllium, corresponding to the proportions $\left(\mathrm{Si}_{5.9} \mathrm{Be}_{0.1}\right)$ and $\left(\mathrm{Si}_{5,7} \mathrm{Be}_{0.3}\right)$, respectively. No evidence for this replacement has ever been found in beryl (Aurisicchio et al. 1988, Artioli et al. 1993). If confirmed by new crystallographic information, this pattern of substitution in bazzite would represent an important departure from that established in beryl.

The possibility of dealing with a crystal structure different, in some details at least, with respect to that of beryl might also account for the existence of a compositional gap between the two minerals in nature (Hänni 1980). Thanks to Mr. Roy Kristiansen from Sellebakk, Norway, we obtained a crystal of bazzite from a granitic pegmatite (Tørdal, Norway) that has provided Xray data of very good quality; similarly, in the mineral collection of the Dipartimento di Scienze della Terra of the University of Milan, one of the cotype specimens from the original find at Baveno (miarolitic occurrence) and belonging to Mr. Bazzi's own collection (see Artini 1915), also was available. For these reasons, we had the possibility of carrying out accurate crystal-structure refinements of bazzite from two different types of environments, including material from the type locality.
EXPERIMENTAL

$X-r a y$ data collection and structure refinement

Crystal data for the two samples here studied are reported in Table 1. For the sample from Baveno, a fragment measuring approximately $0.10 \times 0.12 \times 0.02 \mathrm{~mm}$ was selected from a homogeneous portion of a crystal also used for electron-microprobe analysis (Gramaccioli et al. 2000); this fragment was mounted on a Siemens P4 single-crystal diffractometer using graphitemonochromatized MoK $\alpha$ radiation. The orientation matrix for data collection and the unit-cell dimensions were obtained from least-squares refinement, using the setting angles of 36 reflections with $11.6<\theta<15.6^{\circ}$.

For bazzite from Tørdal, a fragment measuring about $0.15 \times 0.10 \times 0.18 \mathrm{~mm}$ was mounted on a CAD4 single-crystal diffractometer (graphite-monochromatized $\operatorname{Mo} K \alpha$ radiation); the unit-cell dimensions were obtained using 25 reflections with 9.6. $<\theta<20.4^{\circ}$.

Intensity data for the Baveno and Tørdal samples were collected at room temperature with a variable scanrate using the omega-scan technique up to $\theta=30^{\circ}$ for the former and $\theta=40^{\circ}$ for the latter; the different strategy in collecting such data from the two samples was selected in order to take advantage of the better quality of the Norwegian crystal. The $\omega$-scan rate varied from 1 to $20 \% \mathrm{~min}$. Data reduction, including background and Lorentz and polarization corrections, was carried out using the Personal SDP software [Frenz 1992]. An absorption correction was performed as described in Demartin et al. (1992). The structure was refined

TABLE 1. BAZZITE: CRYSTAL DATA

\begin{tabular}{|c|c|c|}
\hline & Baveno & Tørdal \\
\hline Crystal system & \multicolumn{2}{|c|}{ Hexagonal } \\
\hline Space group & \multicolumn{2}{|c|}{ P6/mce (\#192) } \\
\hline$a(\AA)$ & $9.549(2)$ & $9.555(3)$ \\
\hline$c(\AA)$ & $9.163(3)$ & $9.160(2)$ \\
\hline$V\left(\AA^{3}\right)$ & $723.6(3)$ & $732.1(3)$ \\
\hline$Z$ & \multicolumn{2}{|c|}{2} \\
\hline Radiation used & \multicolumn{2}{|c|}{$\operatorname{MoK\alpha }(0.71073 \AA)$} \\
\hline Measured reflections & 4359 & 4543 \\
\hline & 473 unique & 937 unique \\
\hline Diffractometer & Siemens $\mathrm{P} 4$ & Enraf-Nonius CAD4 \\
\hline Transmission factors & $0.930-1.100$ & $0.937-1.074$ \\
\hline$\left(R_{i n t}\right)^{(1)}$ & 0.028 & 0.027 \\
\hline $\operatorname{Max} 2 \theta$ & 60 & 80 \\
\hline $\begin{array}{l}\text { Observed reflections } \\
\{\mathrm{I}>2 \sigma(\mathrm{I})\}\end{array}$ & 325 & 545 \\
\hline Refined parameters & 36 & 39 \\
\hline$R^{(2)}$ & 0.018 & 0.019 \\
\hline$w R^{2(3)}$ & 0.063 & 0.067 \\
\hline $\operatorname{Min} / \max \Delta \rho\left(\mathrm{e} / \AA^{3}\right)$ & $-0.36 / 0.37$ & $-0.38 / 0.53$ \\
\hline
\end{tabular}

(1) $R_{\mathrm{int}}=\left\{\left[\Sigma \mathrm{F}_{\mathrm{o}}{ }^{2}-\mathrm{F}_{\mathrm{o}}{ }^{2}\right.\right.$ (ave) $\left.\left.)\right] /\left[\Sigma \mathrm{F}_{\mathrm{o}}{ }^{2}\right]\right\}$

(2) $R=\left\{\left[\Sigma\left(\mathrm{F}_{0}-\mathrm{F}_{\mathrm{c}}\right)\right] /\left[\Sigma \mathrm{F}_{0}\right]\right.$

(3) $w R^{2}=\left\{\Sigma\left[w\left(F_{0}{ }^{2}-F_{0}{ }^{2}\right)^{2}\right] / \Sigma\left[w\left(F_{0}{ }^{2}\right)^{2}\right]\right\}^{1 / 2}$. 
(SHELX-93) by full-matrix least-squares starting from the atomic coordinates reported by Armbruster et al. (1995). Scattering factors of neutral atoms were used, and anomalous dispersion effects were included in $\mathrm{Fc}$; furthermore, a correction for secondary extinction according to Zachariasen (1963) also was applied. Occupancies of the octahedral and channel sites were refined (vide infra) and are reported in Table 2, together with the final atomic coordinates and equivalent displacement parameters. The anisotropic displacement parameters are given in Table 3 . All sites were labeled according to the convention of Armbruster et al. (1995), together with Wyckoff's notation. Selected interatomic distances are reported in Table 4. Structure factors may be obtained from The Depository of Unpublished Data, CISTI, National Research Council, Ottawa, Ontario K1A OS2, Canada.

\section{REsults AND DISCLSSION}

\section{The $\mathrm{AO}_{6}$ octahedron}

For the sample from Baveno, which contains only minor amounts of $\mathrm{Mg}, \mathrm{Al}$, and $\mathrm{Zr}$ (the total content being less than 0.05 atoms per formula unit), the scattering at the octahedral site was accounted for by refining $[\mathrm{Sc}, \mathrm{Fe}]$ coupled occupancies, starting from the values obtained from the results of the chemical analysis. For the sample from Tordal, the constrained occupancies of $\mathrm{Sc}, \mathrm{Fe}$ and $\mathrm{Al}$ were instead refined; here the presence of significant amounts of $\mathrm{Mn}$ and $\mathrm{Mg}$ is modeled by $\mathrm{Fe}$ and $\mathrm{Al}$, respectively, because of the similarity of the corresponding scattering-factors. The refinement con-

\begin{tabular}{|c|c|c|c|c|}
\hline Site & $x / a$ & $y / b$ & $z / c$ & $B_{e q}\left(\AA^{2}\right)$ \\
\hline \multirow[t]{2}{*}{$A(c)$} & $2 / 3$ & $1 / 3$ & $1 / 4$ & $0.47(2)$ \\
\hline & $2 / 3$ & $1 / 3$ & $1 / 4$ & $0.52(1)$ \\
\hline \multirow[t]{2}{*}{$S i(l)$} & $0.37412(6)$ & $0.09916(7)$ & 0 & $0.40(1)$ \\
\hline & $0.37370(4)$ & $0.09899(4)$ & 0 & $0.38(1)$ \\
\hline \multirow[t]{2}{*}{$W(a)$} & 0 & 0 & $1 / 4$ & $2.69(8)$ \\
\hline & 0 & 0 & $1 / 4$ & $2.45(4)$ \\
\hline \multirow[t]{2}{*}{$N a(b)$} & 0 & 0 & 0 & $1.72(15)$ \\
\hline & 0 & 0 & 0 & $1.76(11)$ \\
\hline \multirow[t]{2}{*}{$01(l)$} & $0.3006(2)$ & $0.2192(2)$ & 0 & $0.84(4)$ \\
\hline & $0.2998(1)$ & $0.2186(1)$ & 0 & $0.92(3)$ \\
\hline \multirow[t]{2}{*}{$\mathrm{O} 2(\mathrm{~m})$} & $0.4819(1)$ & $0.1288(1)$ & $0.1447(1)$ & $0.70(3)$ \\
\hline & $0.4813(1)$ & $0.1286(1)$ & $0.1445(1)$ & $0.79(2)$ \\
\hline \multirow[t]{2}{*}{$B e(f)$} & $1 / 2$ & $1 / 2$ & $1 / 4$ & $0.53(8)$ \\
\hline & $1 / 2$ & $1 / 2$ & $1 / 4$ & $0.66(5)$ \\
\hline
\end{tabular}

First row: bazzite from Baveno; second tow: bazzite from Tørdal. $\mathrm{B}_{\omega_{\mathrm{a}}}=8 \pi^{2} / 3 \Sigma_{\mathrm{i}} \Sigma_{\mathrm{j}} \mathrm{U}_{\mathrm{ij}} \mathrm{a}_{\mathrm{i}} \mathrm{a}_{\mathrm{i}} \mathrm{a}_{\mathrm{i}} \mathrm{a}_{\mathrm{i}}$

* For clarity, Wyckoff's notation of the site follows between parentheses. Refined occupancies for the sample from Baveno: site $A$ [Sc $0.76(3), \mathrm{Fe} \mathrm{0.24(3)]}$ site $\mathrm{Na}[\mathrm{Na} 0.44(2)]$; site $W\left[\mathrm{Cs} 0.10(1), \mathrm{H}_{2} \mathrm{O} 0.90(1)\right]$

Refined occupancies for the sample from Tordal: site $A$ [Sc 0.68(4), Fe 0.26(3), A

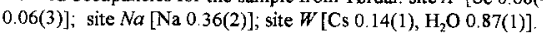

\begin{tabular}{|c|c|c|c|c|c|c|}
\hline Site & $\mathrm{U}(1,1)$ & $\mathrm{U}(2,2)$ & $\mathrm{U}(3,3)$ & $\mathrm{U}(1,2)$ & $\mathrm{U}(1,3)$ & $\mathrm{U}(2,3)$ \\
\hline \multirow[t]{2}{*}{$A$} & $0.0055(2)$ & $\mathrm{U}(1,1)$ & $0.0070(3)$ & $\mathrm{U}(1,1) / 2$ & 0 & 0 \\
\hline & $0.0065(2)$ & $\mathrm{U}(1,1)$ & $0.0068(2)$ & $\mathrm{U}(1,1) / 2$ & 0 & 0 \\
\hline \multirow[t]{2}{*}{ Si } & $0.0052(3)$ & $0.0044(3)$ & $0.0056(3)$ & $0.0024(2)$ & 0 & 0 \\
\hline & $0.0051(2)$ & $0.0045(2)$ & $0.0048(2)$ & $0.0024(1)$ & 0 & 0 \\
\hline \multirow[t]{2}{*}{$W$} & $0.0384(12)$ & $\mathrm{U}(1,1)$ & $0.0255(12)$ & $\mathrm{U}(1,1) / 2$ & 0 & 0 \\
\hline & $0.0344(7)$ & $\mathrm{U}(1,1)$ & $0.0242(8)$ & $\mathrm{U}(1,1) / 2$ & 0 & 0 \\
\hline \multirow[t]{2}{*}{$\mathrm{Na}$} & $0.0157(21)$ & $\mathrm{U}(1,1)$ & $0.0339(37)$ & $\mathrm{U}(1,1) / 2$ & 0 & 0 \\
\hline & $0.0176(16)$ & $\mathrm{U}(1,1)$ & $0.0317(30)$ & $\mathrm{U}(1,1) / 2$ & 0 & 0 \\
\hline \multirow[t]{2}{*}{ OI } & $0.0117(7)$ & $0.0095(7)$ & $0.0134(8)$ & $0.0073(6)$ & 0 & 0 \\
\hline & $0.0136(4)$ & $0.0100(4)$ & $0.0151(4)$ & $0.0087(4)$ & 0 & 0 \\
\hline \multirow[t]{2}{*}{$\mathrm{O} 2$} & $0.0111(5)$ & $0.0085(5)$ & $0.0077(5)$ & $0.0054(4)$ & $-0.0038(4)$ & $-0.0012(4)$ \\
\hline & $0.0125(3)$ & $0.0098(3)$ & $0.0084(3)$ & $0.0059(2)$ & $-0.0042(2)$ & $-0.0013(2)$ \\
\hline \multirow[t]{2}{*}{$B e$} & $0.0066(10)$ & $\mathrm{U}(1,1)$ & $0.0060(14)$ & $0.0025(12)$ & 0 & 0 \\
\hline & $0.0091(7)$ & $\mathrm{U}(1,1)$ & $0.0079(9)$ & $0.0053(7)$ & 0 & 0 \\
\hline
\end{tabular}

Notes: First row: bazzite from Baveno; second row: bazzite from Tørdal

The displacement parameters are of the form: $\exp \left[-2 \pi^{2}\left(\mathrm{U}(1,1) \mathrm{h}^{2} \mathrm{a}^{* 2}-\mathrm{U}(2,2) \mathrm{k}^{2} \mathrm{~b}^{* 2}\right.\right.$ $\left.\left.+\mathbf{U}(3,3) l^{2} \mathrm{c}^{\star 2}+2 \mathrm{U}(1,2) \mathrm{hka} \mathrm{b}^{*}+2 \mathrm{U}(1,3) \mathrm{hla}^{*} \mathrm{c}^{*}+2 \mathrm{U}(2,3) \mathrm{klb}^{*} \mathrm{c}^{*}\right)\right]$

TABLE 4. INTERATOMIC DISTANCES $(\AA)$ AND ANGLES $\left({ }^{\circ}\right)$ BAZZITE AND BERYL

\begin{tabular}{|c|c|c|c|c|}
\hline & Baveno & Tørdal & Furka-tunnel $\left.\right|^{\sharp}$ & beryl $\left.\right|^{5}$ \\
\hline \multicolumn{5}{|c|}{$\mathrm{SiO}_{4}$ tetrahedron } \\
\hline $\mathrm{Si}-\mathrm{O} 1$ & $1.616(2)$ & $1.616(1)$ & $1616(1)$ & $1.592(1)$ \\
\hline $\mathrm{Si}-01$ & $1.616(1)$ & $1.615(1)$ & $1.613(1)$ & $1.594(1)$ \\
\hline Si-O2 $(2 x)$ & $1.614(1)$ & $1.612(1)$ & $1.612(1)$ & $1.620(1)$ \\
\hline Ol-01 & $2.572(2)$ & $2,566(2)$ & $2.558(1)$ & $2.582(1)$ \\
\hline O2-OI (2×) & $2.643(2)$ & $2.644(2)$ & $2.645(1)$ & $2.607(1)$ \\
\hline $\mathrm{O} 2-01(2 \times)$ & $2.654(3)$ & $2.653(2)$ & $2.650(1)$ & $2.638(1)$ \\
\hline $\mathrm{O} 2-\mathrm{O} 2$ & $2.651(2)$ & $2.648(1)$ & $2652(1)$ & $2.668(1)$ \\
\hline $\mathrm{O} 1-\mathrm{Si}-\mathrm{O} 1$ & $105.44(9)$ & $105.12(6)$ & $104.81(5)$ & $108.24(3)$ \\
\hline O2-Si-O1 $(2 \times)$ & $110.53(5)$ & $110.59(4)$ & $110.52(4)$ & $108.42(3)$ \\
\hline $\mathrm{O} 2-\mathrm{Si}-\mathrm{O} 1(2 \times)$ & $109.87(5)$ & $109.99(4)$ & $110.08(3)$ & $110.40(2)$ \\
\hline $\mathrm{O} 2-\mathrm{Si}-\mathrm{O} 2$ & $110.47(6)$ & $110.43(4)$ & $110.68(3)$ & $110.88(2)$ \\
\hline $\mathrm{Si}-\mathrm{O} 1-\mathrm{Si}$ & $165.4(1)$ & $165.12(8)$ & $164.81(7)$ & $168.24(3)$ \\
\hline \multicolumn{5}{|c|}{$\mathrm{BeO}_{4}$ tetrahedron } \\
\hline $\mathrm{Be}-\mathrm{O} 2$ & $1.640(1)$ & $1.641(1)$ & $1.642(\mathrm{I})$ & $1.653(1)$ \\
\hline $\mathrm{O} 2-\mathrm{O} 2(2 \times)$ & $2.493(2)$ & $2.500(1)$ & $2.483(1)$ & $2.335(1)$ \\
\hline $\mathrm{O} 2-\mathrm{O} 2(2 \times)$ & $2.651(2)$ & $2.648(1)$ & $2.650(1)$ & $2.688(1)$ \\
\hline $\mathrm{O} 2-\mathrm{O} 2(2 \times)$ & $2.876(2)$ & $2.874(1)$ & $2.893(1)$ & $3.012(1)$ \\
\hline $\mathrm{O} 2-\mathrm{Be}-\mathrm{O} 2(2 \times)$ & $98.93(5)$ & $99.19(4)$ & $98.28(2)$ & $90.90(2)$ \\
\hline $\mathrm{O} 2-\mathrm{Be}-\mathrm{O} 2(2 \times)$ & $122.50(5)$ & $122.21(4)$ & $123.45(2)$ & $131.40(2)$ \\
\hline $\mathrm{O} 2-\mathrm{Be}-\mathrm{O} 2(2 \times)$ & $107.91(5)$ & $107.89(4)$ & $107.66(2)$ & $108.85(2)$ \\
\hline $\mathrm{Si}-\mathrm{O} 2-\mathrm{Be}$ & $130.44(7)$ & $130.59(5)$ & $130.20(2)$ & $127.05(2)$ \\
\hline \multicolumn{5}{|c|}{$A \mathrm{O}_{6}$ octahedron } \\
\hline $\mathrm{A}-\mathrm{O} 2(6 \times)$ & $2.101(1)$ & $2.105(1)$ & $2.080(1)$ & $1.904(1)$ \\
\hline $\mathrm{O} 2-\mathrm{O} 2(3 \times)$ & $2.493(2)$ & $2.500(1)$ & $2.483(1)$ & $2.335(1)$ \\
\hline $\mathrm{O} 2-\mathrm{O} 2(3 \times)$ & $2.882(3)$ & $2.884(1)$ & $2.868(1)$ & $2.712(1)$ \\
\hline $\mathrm{O} 2-\mathrm{O} 2\left(6^{\times}\right)$ & $3.237(3)$ & $3.242(2)$ & $3.188(1)$ & $2.847(1)$ \\
\hline $\mathrm{O} 2-\mathrm{A}-\mathrm{O} 2(3 \times)$ & $72.81(4)$ & $72.83(3)$ & $73.29(1)$ & $76.40(1)$ \\
\hline $\mathrm{O} 2-\mathrm{A}-\mathrm{O} 2(3 \times)$ & $86.61(4)$ & $86.46(3)$ & $87.15(1)$ & $90.79(1)$ \\
\hline $\mathrm{O} 2-\mathrm{A}-\mathrm{O} 2\left(6^{*}\right)$ & $100.56(4)$ & $100.62(3)$ & $100.06(1)$ & $96.76(1)$ \\
\hline $\mathrm{O} 2-\mathrm{A}-\mathrm{O} 2(3 \times)$ & $171.15(4)$ & $171.27(3)$ & $171.07(1)$ & $170.40(1)$ \\
\hline \multicolumn{5}{|c|}{ Structural channel } \\
\hline $\mathrm{Na}-\mathrm{W}(2 \times)$ & $2.291(1)$ & $2.290(1)$ & 2.295 & \\
\hline $\mathrm{Na}-\mathrm{O} 1(6 \times)$ & $2.572(2)$ & $2.566(1)$ & $2.558(1)$ & \\
\hline
\end{tabular}

\# Data from Armbruster et al. (1995); $\S$ data from Morosin (1972). 
verged to values for the site populations in good agreement with the composition established by analysis (Tables 2, 5). As is well known, bazzite can be considered as the scandium-dominant analogue of beryl, in which most of the $\mathrm{Al}^{3+}$ in the octahedral $A$ sites is replaced by $\mathrm{Sc}^{3+}$, together with a number of other cations, either trivalent or divalent, e.g., $\mathrm{Fe}^{3+}, \mathrm{Fe}^{2+}$, or $\mathrm{Mg}^{2+}$, with widely different radii. Since $\mathrm{Al}^{3+}$ is the smallest of all these cations, the observed $A-\mathrm{O} 2$ distance in bazzite (average $2.103 \AA$ for our data: see Table 4 ) is larger than the corresponding one in beryl, whose average is 1.904 $\AA$ only; as a consequence, the octahedron also becomes considerably larger in size than that occurring for beryl, besides being strongly compressed along $c$ and distorted. Such a flattening is responsible for the greater value of the unit-cell parameter $a$ with respect to that of beryl [9.209 $\AA$ for the pure synthetic beryl, according to Morosin (1972)]. The $A-\mathrm{O} 2$ distances observed in the two samples are statistically identical (Table 4), and are significantly longer than those of bazzite from Furkabasistunnel, this feature most likely depending on the higher content of $\mathrm{Mg}$ for the material from Alpine fissures.

\section{The $\mathrm{BeO}_{4}$ tetrahedron}

The $\mathrm{BeO}_{4}$ tetrahedron shares two edges with two adjacent $A \mathrm{O}_{6}$ octahedra and two vertices with two different $\mathrm{Si}_{6} \mathrm{O}_{18}$ rings. Because the $\mathrm{Si}_{6} \mathrm{O}_{18}$ ring is almost invariable in size, and its flexibility is limited by symmetry constraints, the lengthening of the $A-\mathrm{O} 2$ bonds described above, which takes place on passing from beryl to bazzite and, consequently, that of the O2-O2 edges of the octahedra, imply a modification of the geometry of the adjacent $\mathrm{BeO}_{4}$ tetrahedron (Table 4). As a consequence, this tetrahedron in bazzite becomes less distorted than in beryl, and the $\mathrm{Be}-\mathrm{O}$ distances are subject to significant shortening (average 1.641 versus $1.653 \AA$ in beryl).

\section{Channel sites}

In the open channels of the beryl structure, the metal ions and the $\mathrm{H}_{2} \mathrm{O}$ molecules are located in the $0,0,1 / 4$ (a) and $0,0,0(b)$ positions of the $P 6 / m c c$ space group, using Wyckoff's labels. According to most authors, for instance, Hawthorne \& Černy (1977), $\mathrm{H}_{2} \mathrm{O}$ and the larger alkali ions $\left(\mathrm{Cs}^{+}, \mathrm{Rb}^{+}\right.$, and $\left.\mathrm{K}^{+}\right)$should occupy the $a$ position, whereas the $\mathrm{Na}^{+}$ions should instead lie at $b$, i.e., at the center of the $\mathrm{Si}_{6} \mathrm{O}_{18}$ rings. On considering the case of a unique natural example of beryl containing no $\mathrm{H}_{2} \mathrm{O}$, and on grounds of reliable crystallographic data, Aurisicchio et al. (1988) inferred that in this anhydrous sample, $\mathrm{Na}^{+}$occupies instead the $a$ site exclusively, together with all the heavier alkali ions; similarly, for a series of $\mathrm{H}_{2} \mathrm{O}$-containing natural samples of beryl, the same authors have noticed that the residual electrondensity maxima in the $a$ and $b$ positions can be ac-
TABLE 5. CHEMICAL COMPOSITION* OF BAZZITE FROM BAVENO AND TøRDAL

\begin{tabular}{|c|c|c|c|c|c|c|c|}
\hline & \multirow{2}{*}{$\begin{array}{c}\text { Baveno } \\
\text { (1) }\end{array}$} & \multirow{2}{*}{$\begin{array}{c}\text { Tordal } \\
\text { (2) }\end{array}$} & & \multicolumn{2}{|c|}{ Baveno } & \multicolumn{2}{|c|}{ Tørdal } \\
\hline & & & & A & B & A & B \\
\hline $\mathrm{MgO} w t \%$ & 0.13 & 0.10 & $\mathrm{Mg} a p f u$ & 0.019 & & 0.014 & \\
\hline $\mathrm{Al}_{2} \mathrm{O}_{3}$ & 0.14 & 0.80 & $\mathrm{Al}$ & 0.016 & & 0.090 & 0.12 \\
\hline $\mathrm{MnO}$ & 0.10 & 1.43 & $\mathrm{Mn}$ & 0.009 & & 0.112 & \\
\hline $\mathrm{Fe}_{2} \mathrm{O}_{3}$ & 6.62 & 5.70 & $\mathrm{Fe}$ & 0.496 & 0.48 & 0.399 & 0.52 \\
\hline $\mathrm{Sc}_{2} \mathrm{O}_{3}$ & 16.24 & 14.50 & $\mathrm{Sc}$ & 1.409 & 1.52 & 1.182 & 1.46 \\
\hline \multirow[t]{2}{*}{$\mathrm{ZrO}_{2}$} & 0.30 & & $\mathrm{Zr}$ & 0.014 & & & \\
\hline & & & $\Sigma A$ & 1.963 & & 1.797 & \\
\hline $\mathrm{Na}_{2} \mathrm{O}$ & 2.13 & 1.60 & $\mathrm{Na}$ & 0.412 & 0.44 & 0.292 & 0.36 \\
\hline $\mathrm{K}_{2} \mathrm{O}$ & 0.00 & 0.13 & $\mathrm{~K}$ & 0.000 & & 0.017 & \\
\hline $\mathrm{Rb}_{2} \mathrm{O}$ & 0.00 & 0.25 & $\mathrm{Rb}$ & 0.000 & & 0.015 & \\
\hline $\mathrm{Cs}_{2} \mathrm{O}$ & 2.30 & 2.93 & $\mathrm{Cs}$ & 0.096 & 0.10 & 0.116 & 0.14 \\
\hline \multirow[t]{2}{*}{$\mathrm{CaO}$} & 0.00 & & $\mathrm{Ca}$ & 0.000 & & & \\
\hline & & & $\Sigma B$ & 0.508 & & 0.440 & \\
\hline \multirow{3}{*}{$\begin{array}{l}\mathrm{SiO}_{2} \\
\mathrm{BeO}\end{array}$} & 58.18 & 58.00 & $\mathrm{Si}$ & 6.000 & & 5.431 & \\
\hline & ${ }^{8} 12.11$ & 14.50 & $\mathrm{Be}$ & ${ }^{8} 0.000$ & & 0.569 & \\
\hline & & & $\Sigma C$ & 6.000 & & 6.000 & \\
\hline \multirow{3}{*}{$\mathrm{Li}_{2} \mathrm{O}$} & & & $\mathrm{Be}$ & 3.000 & & 2.909 & \\
\hline & & 0.24 & $\mathrm{Li}$ & & & 0.091 & \\
\hline & & & $\Sigma D$ & 3.000 & & 3.000 & \\
\hline $\mathrm{H}_{2} \mathrm{O}$ & 2.72 & 1.10 & $\mathrm{H}$ & & 1.80 & 0.699 & 1.94 \\
\hline total & 100.97 & 101.28 & & & & & \\
\hline
\end{tabular}

- Normalized to $9(\mathrm{Si}+\mathrm{Be})$ atoms per formula unit (apfu)

A: determined by chemical analysis; $B$ : determined from the crystal-structure refinement. ${ }^{8}$ Obtained by assuming $\mathrm{Be} / \mathrm{Si}=0.5$.

"Calculated on the basis of the crystal-structure refinement.

Samples: (1) Cotype specimen from the collection of the Dipartimento di Scienze della Terra, Università di Milano (Gramaccioli et al. 2000). (2) From Juve \& Bergstel (1990).

counted for almost exactly by locating $\mathrm{Na}^{+}$and all the other alkali ions noted in the results of the electron-microprobe analyses in $a$, and the $\mathrm{H}_{2} \mathrm{O}$ molecules in $b$, in contrast to the model of Hawthorne and Čnery (1977). However, in general, there is no reason why the $\mathrm{H}_{2} \mathrm{O}$ molecules should not occupy the $a$ as well the $b$ position, and such a possibility could account for the presence of two types of $\mathrm{H}_{2} \mathrm{O}$ in the infrared spectra (Wood \& Nassau 1967, Polupanova et al. 1985).

On the basis of the refined occupancies in the case of the bazzite from Furkabasistunnel, Armbruster et al. (1995) suggested that the $a$ position essentially contains $\mathrm{H}_{2} \mathrm{O}$ molecules, whereas the cations $\left(\mathrm{Na}^{+}\right.$and $\left.\mathrm{Ca}^{2+}\right)$ are located instead in $b$, the occupancy in this position corresponding to $0.46 \mathrm{Na} p f u$. However, since the amount of $\mathrm{Na}+\mathrm{Ca}$ determined by electron-microprobe analysis corresponds to an occupancy of $0.32 \mathrm{Na} p f u$ only, the possibility that this site also contains small amounts of heavy elements or $\mathrm{H}_{2} \mathrm{O}$ (or both) cannot be ruled out.

In the present study, the refined occupancies of the $b$ site for our samples from Baveno and Tørdal can be reproduced very well by locating in this position an amount of Na corresponding to the chemical composition as determined by electron-microprobe analysis; the remaining alkali atoms can be placed instead in the $a$ 
site, together with most of the $\mathrm{H}_{2} \mathrm{O}$ molecules, thereby confirming the validity of the proposal of Hawthorne \& Černý (1977) also for bazzite.

The $\mathrm{Si}_{6} \mathrm{O}_{18}$ ring

The pattern of bond distances and angles observed for the $\mathrm{SiO}_{4}$ tetrahedra is identical to that observed in bazzite from Furkabasistunnel (Armbruster et al. 1995), and is similar to what has been found for samples of Na-rich beryl (Aurisicchio et al. 1988). On introducing $\mathrm{Na}^{+}$at the center of the $\mathrm{Si}_{6} \mathrm{O}_{18}$ rings, as invariably happens in bazzite (see above), in order to satisfy the bondvalence requirements of oxygen, the $\mathrm{Si}-\mathrm{O} 1$ distances should become longer than those occurring for alkalifree beryl; however, at the same time, the $\mathrm{Si}-\mathrm{O} 2$ distances should be shortened to maintain an acceptable bond-valence sum for silicon (Table 4 ). The average $\mathrm{Si}-$ $O$ distance is 1.615 and $1.614 \AA$, respectively, for our samples, and is $1.613 \AA$ for bazzite from Furkabasistunnel; these values are only slightly but significantly larger than the corresponding values for beryl (average $1.609 \AA$. according to Aurisicchio et al. 1988). Rather than an inferred partial substitution of $\mathrm{Si}$ by $\mathrm{Be}$ (see below), such an increase is much more likely to be due to the strain occurring in the $\mathrm{Si}_{6} \mathrm{O}_{18}$ ring as a consequence of having replaced $\mathrm{Al}^{3+}$ in the octahedral sites with larger cations (see above).

As we have seen, the chemical composition of two specimens reported by Chistyakova et al. (1966) and Juve \& Bergstøl (1990) was interpreted to show partial substitution of Si by Be. The sample from Tørdal is presumably similar to our material from that locality, showing the more marked degree of substitution. Therefore, after completion of the crystal-structure refinement independently for both our samples, we have considered the possibility of carrying out a further stage by also allowing the occupancy of the Si sites to vary. The final result can be considered to be at least partially dependent upon the number of electrons assigned to the $\mathrm{Be}$, $\mathrm{Si}$, and $\mathrm{O}$ atoms, as well as upon the range of $\sin \theta / \lambda$ considered, since the scattering curves are not strictly proportional to the number of electrons. There are also problems if corrections for extinction are inadequate. The results are reported in Table 6; the various attempts

TABLE 6 REFINED VALUES OF THE OCCUPANCY OF THE Si SITE*

\begin{tabular}{lccc}
\hline & bazzite, Baveno & bazzite, Tørdal & beryl \\
\hline Neutral atoms & 0.948 & 0.960 & 0.986 \\
lons & 0.968 & 0.974 & 0.978 \\
$\sin \theta / \lambda>0.4$ neutral atoms & 1.010 & 1.038 & 1.034 \\
$\sin \theta / \lambda>0.4$ ions & 0.966 & 1.016 & 1.014 \\
\hline
\end{tabular}

* The estimated standard deviation for all the cases shown above is 0.001 differ because the form factors of neutral atoms or ions have been alternatively considered, or because a maximum value of $\sin \theta / \lambda$ for the reflections has been introduced in some cases.

On examining these results, a deviation from the theoretical value of the occupancy (1.00) can be noticed for bazzite in all cases. The deviation seems significant on the basis of the estimated standard deviations obtained from the final cycles of the least squares; however, the possible presence of systematic errors should be seriously considered. In the case of beryl, there is general and well-grounded agreement about the absence of such substitution of Si by Be (Aurisicchio et al. 1988, Artioli et al. 1993); the absence of significant Be-for-Si substitution in beryl has also been proved by our lattice-dynamics calculations (Pilati et al. 1997), since our theoretical estimates of the atomic displacement parameters (ADP) of the Si atoms almost match the corresponding experimental values, whereas the replacement of some $\mathrm{Si}$ by Be would lead to considerably higher values of the ADP.

As a test, we have refined the structure of a sample of beryl under the same conditions, and the data were collected and processed using the same equipment and routines. These data, also reported in Table 6 , might constitute a good standard for comparison. An examination of these results and a comparison with the corresponding data for bazzite reveal no significant difference between the two minerals in this respect. Therefore, no clear evidence has been obtained in favor of the possibility of Be-for-Si substitution. Furthermore, on examining the results of the different models tested for bazzite, the values of the occupancy are clearly ambiguous because, even for the same sample, they can be either higher or lower than 1.00; therefore, we conclude that their actual uncertainty is much greater than the corresponding estimated standard deviation, owing to the presence of systematic errors in the collected data (including their treatment) and to the inadequacy of the scattering curves used.

\section{ACKNOWLEDGEMENTS}

The financial assistance of the Italian National Research Council (C.N.R.), and of the MURST Project "Transformations, reactions, ordering in minerals", as well as useful help by Dr. Alessandro Minaglia are gratefully acknowledged. Drs. T. Armbruster, L.A. Groat and R.F. Martin provided useful suggestions for revising the manuscript.

\section{REFERENCES}

Armbruster, T., Libowitzky, E., Diamond, L., Auernhammer, M., Bauerhansl, P., Hoffmann, C., Irran, E., Kurka, A. \& Rosenstingl, H. (1995): Crystal chemistry and optics of bazzite from Furkabasistunnel (Switzerland). Mineral. Petrol. 52, 113-126. 
ArTiNi, E. (1915): Due minerali di Baveno contenenti terre rare: weibyeite e bazzite. Rend. Accad. Lincei 24, 313-319.

Artioli, G., Rinaldi, R., STÁHL, K. \& ZanazZi, P. F. (1993): Structure refinement of beryl by single-crystal neutron and $\mathrm{X}$-ray diffraction. Am. Mineral. 78, 762-768.

Aurisicchio, C., Fioravanti, G., Grubessi, O. \& Zanazzi, P.F. (1988): Reappraisal of the crystal chemistry of beryl. Am. Mineral. 73, 826-837.

BERGSTøL, S. \& JuVE, G. (1988): Scandian ixiolite, pyrochlore and bazzite in granite pegmatite in Tørdal, Telemark, Norway. A contribution to the mineralogy and geochemistry of scandium and tin. Mineral. Petrol. 38, 229-243.

Chistyakova, M.B., Moleva, V.A. \& Razmanova, Z.P. (1966): Bazzite found for the first time in the USSR. Dokl. Acad. Sci. USSR, Earth Sci. Sect. 169, 158-161.

Demartin, F., Gramaccioli, C.M. \& Pilati, T. (1992): The importance of accurate crystal structure determination of uranium minerals. II. Soddyite $\left(\mathrm{UO}_{2}\right)_{2}\left(\mathrm{SiO}_{4}\right) \cdot 2 \mathrm{H}_{2} \mathrm{O}$. Acta Crystallogr. C48, 1-4

Frenz, B. A. \& Associates, Inc. (1992): Personal SDP Reference Manual. College Station, Texas.

Gramaccioli, C.M., Dieli.a, V., Demartin, F., Orlandi, P.\& Campostrini, I. (2000): Cesian bazzite and thortveitite from Cuasso al Monte (Varese): a comparison with the corresponding scandium minerals from Baveno. Can. Mineral. 38, 1409-1418.
HÄNNI, H.A. (1980): Mineralogische und mineralchemische Untersuchungen an Bervll aus alpinen Zerrklïften. Inaugural dissertation, Univ. of Basel, Basel, Switzerland.

Hawthorne, F.C. \& ČRnY, P. (1977): The alkali-metal positions in Cs-Li beryl. Can. Mineral. 15, 414-421.

Juve, G. \& BergstøL, S. (1990): Caesian bazzite in granite pegmatite in Tørdal, Telemark, Norway. Mineral. Petrol. $43,131-136$.

Morosin, B. (1972): Structure and thermal expansion of beryl. Acta Crystallogr. B28, 1899-1903.

Pilati, T., Demartin, F. \& Gramaccioli, C.M. (1997): Lattice-dynamical evaluation of thermodynamic properties and atomic displacement parameters for beryl using a transferable empirical force field. Am. Mineral. 82, 1054-1062.

Polupanova, T.I., Petrov, V.L., Kruzhalov, A.V., LASKOVENKOV, A.F. \& Nikitin, V.S. (1985): The thermal stability of beryl. Geochem. Int. 22, 11-13

WOOD, D.L. \& NASSAU, K. (1967): Infrared spectra of foreign molecules in beryl. J. Chem. Phys. 47, 2220-2228.

ZACHARIASEN, W.H. (1963): The secondary extinction correction. Acta Crystallogr. 16, 1139-1144.

Received February 9, 2000, revised manuscript accepted November 8,2000 . 